\title{
Implementation of Multi-attribute Rating Technique Simple in Selection of Acceptance Scholarship of PMDK (Case Study: STMIK Widya Cipta Dharma)
}

\section{Vilianty Rafida}

STMIK Widya Cipta Dharma, Samarinda, 75123, Indonesia

Email: vilianty@wicida.ac.id

\section{Wiwik Widiyatni}

STMIK Widya Cipta Dharma, Samarinda, 75123, Indonesia

Email: wiwik@wicida.ac.id

\section{Bartolomius Harpad}

STMIK Widya Cipta Dharma, Samarinda, 75123, Indonesia

Email: arvenusharpad@gmail.com

\author{
Ekawati Yulsilviana \\ STMIK Widya Cipta Dharma, Samarinda, 75123, Indonesia \\ Email: ekawicida@gmail.com
}

Received: 19 March 2020; Accepted: 25 June 2020; Published: 08 February 2021

\begin{abstract}
This research aimed to create a decision support system for admission selection of PMDK scholarship pathway using the SMART (Simple Multi-Attribute Rating Technique) method with web-based and if this research was successful, it could help STMIK Widya Cipta Dharma to select PMDK scholarship should be given to a student of STMIK Widya Cipta Dharma. PMDK is the tittle of scholarship for interest and talent scouting. This research was conducted at STMIK Widya Cipta Dharma Samarinda, a method of data collection used interviews, that asked questions related to the selection of PMDK scholarship admissions by observation directly to STMIK Widya Cipta Dharma Samarinda. This research development system method used the development of a decision support system method. The software model used PHP programming language and database using MYSQL. The final result of this research is a decision support system for admission selection of the PMDK scholarship pathway using the SMART (Simple Multi-Attribute Rating Technique) method with web-based, can help selection of PMDK scholarship faster by admin, and provide information to students. So contribution of this paper is gives a best recommendation for selection of PMDK scholarship using decision support systems.
\end{abstract}

Index Terms: Decision Support Systems, Scholarships, SMART, Web.

\section{Introduction}

In this modern era, all matters will be related to the ease of managing data without taking a long time. Therefore, the solution is to form a computerized system to find the best results. The system is a network of procedures that are interconnected, gathered together to carry out activities or to perform certain goals [1-3]. This computerized system has been used by various government agencies and educational institutions. The aim is to improve performance and time efficiency. STMIK WIDYA CIPTA DHARMA is a private tertiary institution addressing Jl. Yamin Samarinda. In its operational process, the Collage has facilities and technology, namely the presence of several computers that are used by financial department, in processing for searching data it is still right on target to obtain the best value.

PMDK or Interest and Ability Tracking is an entry point organized by each specific university or institute to screen students who have superior talents and academic abilities compared to prospective students. Decisions are the result of thinking in the form of choosing one among several alternatives that can be used to solve the problem at hand $[2,4-7]$. 
PMDK entrance not only looks at the variable academic value of prospective students but their talent. The time for holding PMDK depends on the schedule arranged by the university or institute. What must be known from PMDK is that not all universities use PMDK as an entry point to these tertiary institutions. So for prospective students who want to enter the PMDK pathway, it is highly recommended to seek information in advance about whether the university or institute is intended to offer the PMDK entry point.

The Scholarship is income for those who receive it. The definition of scholarship is an additional economic capability by name and in any form that is received or obtained from sources from Indonesia or outside Indonesia that can be used for consumption or to increase the wealth of taxpayers (WP). A lot of money (fees) provided by the collage agencies has been budgeted in the APBD funds. Funds will be determined based on how much income from the collage and how much budget is needed.

STMIK Widya Cipta Dharma is a private collage and the best collage especially in the IT field in East Kalimantan which has various study programs, including Informatics Engineering, Information Systems, and Information Management that can create graduates who can work professionally

At STMIK Widya Cipta Dharma there are several Scholarships, one of which is the Selection of Interest and Ability Search Scholarship (PMDK), the Scholarship Selection of the PMDK Pathway is specifically for new students and has been held in one semester to the end of the semester, but in the selection is still less professional because only taken from GPA and manually.

\section{A. Problem Formulation}

As explained in the background above, a problem statement was made, "How is the PMDK Scholarship Acceptance Support Decision Selection System using the Smart method on Widya Cipta Dharma STMIK Websitebased?"

\section{B. Purpose}

The purpose of this study is to produce a decision support system for PMDK scholarship selection using the Smart STMIK Widya Cipta Dharma method, so it is expected to be able to assist in the selection of PMDK scholarship pathways at STMIK Widya Cipta Dharma.

\section{Limitation Problems}

For the writer of this final project to be more focused, the writer makes a limitation of the problem in this final project as follows:

1. This decision support system is created using the Smart method.

2. Making this Decision Support System is focused only on determining the STMIK PMDK Scholarship Selection Widya Cipta Dharma.

3. The criteria chosen in the selection of prospective Scholarship Recipients include several criteria, namely the income of parents, champions of non-academic achievements, GPA, and Student Organizations.

\section{Development Methodology}

System development aids are tools that are used in the stage of taking a good system, used as a tool, as a modeling tool that is possible for system professionals to describe the system as a network of functional processes needed by each other with data flow both manually and computerized [8-11]. The research will be carried out through several stages of the decision support system as follows:

1. The Intelligence stage is carried out to identify and identify the problem that is happening, usually, an analysis is conducted. From the research methods applied, obtained data used in making this system. From these data, an analysis can be made to facilitate decision making in selecting prospective recipients of PMDK Pathway Scholarships in research.

2. The Design Phase in this stage is designed and designed.

3. The Choice Stage where a real decision is made and a commitment are taken to follow certain follow-up actions. This phase includes the search, evaluation, and recommendations for a solution that is right for the model.

4. Implementation Phase is carried out the application and implementation of the system design that has been made at the planning stage and the implementation and implementation of alternative actions that have been selected at the selection stage. reviewed.

Each stage is carried out sequentially from the first step to the last step, each step that has been completed must be 


\section{Literature Review}

A. System

The system is a network of interrelated procedures, gathered together to carry out activities or to carry out certain goals. The characteristics of a system so that the system is said to be a good system are as follows $[9,12]$ :

\section{Components}

A system consists of interacting which means mutual System components consist of parts of the system.

\section{System Boundary}

The system boundary is an area that limits between a system with other systems or with the external environment. This system limit allows a system to be seen as a single unit. The limitation of a system shows the scope of the system.

\section{Environment System}

The environment outside the system (environment) is outside the boundaries of the system that affect system operation. The environment can be beneficial which must be maintained and the detriment must be maintained and controlled if it will not interfere with the survival of the system.

\section{Interface System}

The connecting system is a media liaison between subsystems with other subsystems. Through this link allows resources to flow from one subsystem to another subsystem. The output from the subsystem will be input to other subsystems through the connector.

\section{Input System}

Enter the system is the energy put into the system, which can be in the form of maintenance and enter the signal. maintenance input is the energy put into the system to operate. Signal input is the energy processed to obtain the output.

\section{Output System}

The system output is the result of energy being processed and classified into useful output and residual waste.

\section{System Processing}

A system becomes a part of the processor that will convert inputs into outputs. The production system will process raw materials into finished materials, the accounting system will process data into financial reports.

\section{System Objectives}

A system must have a goal or target. The goal of the system is to determine the input needed by the system and the output that the system will produce, stated in the characteristics of a system

Based on the opinions of the experts above about the system, it can be concluded that the system is an interconnected element and interact with others in unity to achieve a certain goal.

\section{B. Decision}

Decisions are the result of thinking in the form of a choice among several alternatives that can be used to solve the problem at hand [13].

C. MYSQL

MySQL is an RDBMS that is distributed free of charge under the GPL (General Public License), where everyone is free to use MySQL, but may not be a derivative product that is closed source or commercial $[14,15]$.

\section{Website}

The website is a collection of pages that are interconnected, which are then online using a local network or the internet $[16,17]$.

\section{Result and Discussion}

\section{A. The SMART Method Modeling Process}

The calculation steps are carried out in the Simple Multi-Attribute Rating Technique method; 
1. Determine the weight of each goal factor (Goal Weight Factor) with a Range between 1 to 10

2. Normalized Weight Factor Count of each goal by comparing the value of each goal weight (Goal Weight Factor) to the total number of goal weight (Total Goal Weight Factor). As stated in the formula for calculating Normalized Weight Factor (1).

$$
\text { Normalized Weight Factor }=\frac{\text { Goal Weight Factor }}{\text { Total Goal Weight Factor }}
$$

3. Compare the values of the same criteria from each package. Find the difference in value between the highest value and the lowest value. The difference results are divided by the number of alternative packages to determine the class interval of each criterion. As stated in the formula for calculating the interval (2).

$$
\text { Interval }=\frac{\text { Goal Weight Factor }}{\text { Skala }}
$$

4. After getting the range of classes on each criterion, we can determine the weight value for each alternative (intervals 1-5)

5. After process number 4, each weight is given a new value after being determined, namely through the utility score. This is the normalization of raw data (between 0-1), according to the foundation of the Multi-Attribute Utility Theory (MAUT). It is listed in the Table 1. Utility Score.

\begin{tabular}{|c|c|}
\hline Normalized Score & Utility Score \\
\hline 1 & 0 \\
\hline 2 & 0.25 \\
\hline 3 & 0.5 \\
\hline 4 & 0.75 \\
\hline 5 & 1 \\
\hline
\end{tabular}

Table 1. Utility Score

6. Determine the percentage value of each alternative by multiplying the value obtained in process no. 5 with the Normalized Weight factor value. The total value of the multiplication process and the total multiplied by $100 \%$

7. After obtaining the percentage value of each alternative, it can be determined that the outcome recommendation that is closest to the predetermined goal, that is, the package that has the highest percentage value. This is ranking [2,5,18].

The solution for the model in this study is to use the SMART (Simple Multi-Attribute Rating Technique) method. Variables used in this decision support system are student organizations, GPA, and non-academic achievement champions, then it will be planned that a system will be implemented into a form of decision support system for PMDK scholarship selection on STMIK Widya Cipta Dharma using the Web programming language where PHP is the programming language by prioritizing user convenience in using this system so that it can help and facilitate STMIK Widya Cipta Dharma in selecting PMDK Scholarship according to needs. The following is an example of PMDK Scholarship selection calculation:

\begin{tabular}{|c|c|c|c|c|c|c|c|c|}
\hline Name & Criteria & Weight & Input & Utility & Normalization & Results & SMART & Decision \\
\hline \multirow{4}{*}{$\underset{\tilde{\Xi}}{\stackrel{\widetilde{z}}{\partial}}$} & Parents' Earnings & $30 \%$ & $<1.000 .000$ & 100 & 0.3 & 30 & \multirow{4}{*}{86} & \multirow{4}{*}{$\begin{array}{l}\text { Very } \\
\text { decent }\end{array}$} \\
\hline & GPA & $40 \%$ & $\mathrm{GPA} \geq 3.00$ & 100 & 0.4 & 40 & & \\
\hline & $\begin{array}{c}\text { Non Academic } \\
\text { Achievement }\end{array}$ & $20 \%$ & $\begin{array}{l}\text { 1st Place } \\
\text { Province }\end{array}$ & 40 & 0.2 & 8 & & \\
\hline & organizations & $10 \%$ & $\begin{array}{l}\text { general } \\
\text { Secretary }\end{array}$ & 80 & 0.1 & 8 & & \\
\hline
\end{tabular}

Table 2. Calculation of Scholarship Selection Is Very Decent

\begin{tabular}{|c|c|c|c|c|c|c|c|c|}
\hline Name & Criteria & Weight & Input & Utility & Normalization & Results & SMART & Decision \\
\hline \multirow{4}{*}{ 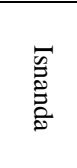 } & Parents' Earnings & $30 \%$ & $<1.000 .000$ & 100 & 0.3 & 30 & \multirow{4}{*}{74} & \multirow{4}{*}{ Worthy } \\
\hline & GPA & $40 \%$ & $\mathrm{GPA} \geq 3.00$ & 100 & 0.4 & 40 & & \\
\hline & $\begin{array}{c}\text { Non Academic } \\
\text { Achievement }\end{array}$ & $20 \%$ & $\begin{array}{l}\text { 2nd place in } \\
\text { the Province }\end{array}$ & 20 & 0.2 & 4 & & \\
\hline & organizations & $10 \%$ & no & 0 & 0.1 & 0 & & \\
\hline
\end{tabular}

Table 3. Calculation of Worth Scholarship Selection 
Table 4. Calculation of Scholarship Selection Considered

\begin{tabular}{|c|c|c|c|c|c|c|c|c|}
\hline Name & Criteria & Weight & Input & Utility & Normalization & Results & SMART & Decision \\
\hline \multirow{4}{*}{$\begin{array}{l}\text { T⿱⺌兀) } \\
\stackrel{\vec{\Xi}}{\Xi}\end{array}$} & Parents' Earnings & $30 \%$ & $<1.000 .000$ & 100 & 0.3 & 30 & \multirow{4}{*}{60} & \multirow{4}{*}{ considered } \\
\hline & GPA & $40 \%$ & $\mathrm{GPA} \geq 3.00$ & 0 & 0.4 & 0 & & \\
\hline & $\begin{array}{c}\text { Non Academic } \\
\text { Achievement }\end{array}$ & $20 \%$ & $\begin{array}{l}\text { 1st National } \\
\text { Champion }\end{array}$ & 100 & 0.2 & 20 & & \\
\hline & organizations & $10 \%$ & Chairman & 100 & 0.1 & 10 & & \\
\hline
\end{tabular}

Table 5. Calculation of Scholarship Selection Is Not Worth It

\begin{tabular}{|c|c|c|c|c|c|c|c|c|}
\hline Name & Criteria & Weight & Input & Utility & Normalization & Results & SMART & Decision \\
\hline \multirow{4}{*}{ 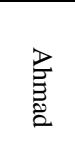 } & Parents' Earnings & $30 \%$ & $<1.000 .000$ & 100 & 0.3 & 30 & \multirow{4}{*}{38} & \multirow{4}{*}{$\begin{array}{c}\text { Not } \\
\text { feasible }\end{array}$} \\
\hline & GPA & $40 \%$ & $\mathrm{GPA} \geq 3.00$ & 0 & 0.4 & 0 & & \\
\hline & $\begin{array}{l}\text { Non Academic } \\
\text { Achievement }\end{array}$ & $20 \%$ & $\begin{array}{l}\text { 1st Place } \\
\text { Province }\end{array}$ & 40 & 0.2 & 8 & & \\
\hline & organizations & $10 \%$ & There is no & 0 & 0.1 & 0 & & \\
\hline
\end{tabular}

Information on Table 2-5

Value $\mathrm{Wj} \quad=$ Weight value / total number of weights

Result $\quad=$ Utility $* \mathrm{Wj}$

SMART $\quad=$ Sum of all Results values

In the Table, 2 the PMDK Scholarship selection calculation is very feasible, with the name Huda having 4 criteria namely Parent Income with a weight value of 30, GPA with a Weight of 40, Non-academic Achievement with a weight value of 20, active student organizations with a weight value of 10. STMIK Widya Cipta Dharma input yes for the criteria for Parent Income, grade point $\geq 3.00$ for GPA, Champion 1 at the provincial level for Nonacademic achievement criteria and general secretary is for student organizations, from these inputs the value of Parent Income Utility is 100, GPA of 100, non-academic achievement of 100, and student organizations of 80.

Wj value for the Parents' Income criteria was obtained from 30/100 =0.3, GPA was obtained from 40/100 =0.4, non-academic achievements $20 / 100=0.2$, student organizations $10 / 100=0.1$.

The value of the results for the Parents' Income criteria utility value X value $\mathrm{Wj}, 100 \mathrm{X} 0.3=30$, GPA $100 \mathrm{X} 0.4=$ 40 , champion 1 province $40 \times 0.2=8$, student organizations $80 \times 0.1=8$. The value of SMART is the sum of the results for each criterion is $30+40+8+8=86$ and the decision to have the name Huda is declared very feasible.

In Table 3, the PMDK Scholarship selection calculation is feasible, with the name Huda having 4 criteria namely Parent Income with a weight value of 30, GPA with a Weight of 40, Non-academic Achievement with a weight value of 20, active student organizations with a weight value of 10. The STMIK Widya Cipta Dharma input yes for the criteria for Parents' Income, grade point $\geq 3.00$ for the GPA, Champion 2 at the provincial level for Non-academic achievement criteria and none for student organizations, from these inputs the value of the Parent Income Utility is 100, GPA of 100, a non-academic achievement of 20 , and a student organization of 0 .

$\mathrm{Wj}$ value for the Parents' Income criteria was obtained from 30/100 =0.3, GPA was obtained from 40/100 =0.4, non-academic achievements $20 / 100=0.2$, student organizations $10 / 100=0.1$.

The value of the results for the Parents' Income criteria utility value $\mathrm{X}$ value $\mathrm{Wj}, 100 \mathrm{X} 0.3=30, \mathrm{GPA} 100 \mathrm{X} 0.4=$ 40 , champion 2 provinces $20 \times 0.2=4$, student organizations 0 X0.1 $=0$. The SMART value is the sum the value of each criterion is $30+40+4+0=74$ and the decision that there is a Huda name is declared appropriate.

In Table 4 the selection calculation for the PMDK Scholarship is feasible, with the name Huda having 4 criteria namely Parent Income with a weight value of 30, GPA with a Weight of 40, Non-academic Achievement with a weight value of 20, active student organizations with a weight value of 10. The STMIK Widya Cipta Dharma input yes for the criteria for Parent Income, grade point $<3.00$ for GPA, Provincial Champion 2 for Non-academic achievement criteria and general chairman for student organizations, from these inputs the value of Parent Income Utility of 100, GPA of 0, a non-academic achievement of 20, and a student organization of 100 .

$\mathrm{Wj}$ value for the Parents' Income criteria was obtained from 30/100 $=0.3$, GPA was obtained from 40/100 $=0.4$, non-academic achievements $20 / 100=0.2$, student organizations $10 / 100=0.1$.

The value of the results for the Parents' Income criteria utility value X value $\mathrm{Wj}, 100 \mathrm{X} 0.3=30$, GPA 0 X $0.4=0$, 1 st National champion $100 \times 0.2=20$, student organizations $100 \times 0.1=10$. SMART value is the sum of values the results of each criterion are $30+0+20+10=60$ and the decision to find Huda's name is considered.

In Table 5 the selection calculation for the PMDK Scholarship is feasible, with the name Huda having 4 criteria namely Parent Income with a weight value of 30, GPA with a Weight of 40, Non-academic Achievement with a weight value of 20, active student organizations with a weight value of 10. The STMIK Widya Cipta Dharma input yes for the Parent Income Criteria, grade point $<3.00$ for GPA, provincial national Champion for Non-academic achievement criteria and none for student organizations, from these inputs the value of Parent Income Utility is 100, GPA of 0, nonacademic achievement of 100, and student organizations of 0 . 
Wj value for the Parents' Income criteria was obtained from 30/100 $=0.3$, GPA was obtained from 40/100 $=0.4$, non-academic achievements $20 / 100=0.2$, student organizations $10 / 100=0.1$.

The value of the results for the Parents' Income criteria utility value X value $\mathrm{Wj}, 100 \mathrm{X} 0.3=30$, GPA 0 X $0.4=0$, champion 1 Profits $40 \times 0.2=8$, student organizations $0 \times 0.1=0$. SMART value is the sum of values the results of each criterion were $30+0+8+0=38$ and the decision that there was a Huda name was declared unfeasible. In Table 5 the PMDK Scholarship selection calculation is feasible, with the name Huda having 4 criteria namely Parent Income with a weight value of 3 .

\section{B. Sequence Diagram}

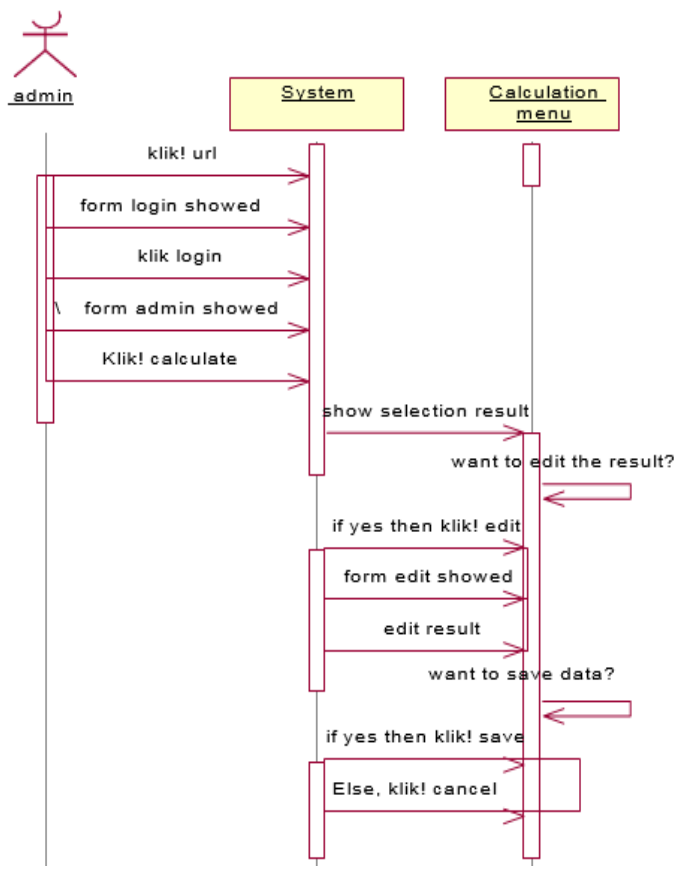

Fig. 1. Sequence Diagram

In Fig. 1 sequence diagram calculation menu illustrates the event a user accesses the calculation form on the website. Where Admin when entering the calculation form can see the results of the calculation, if the admin will edit the assessment click edit will then appear edit form then click save to save changes and click cancel to cancel changes.

\section{Implementation}

Fig. 2 is the Login page. The login page is the page to enter the main menu page on the system. This login page is used by the admin to enter email and password then click the login button to go to the main page.

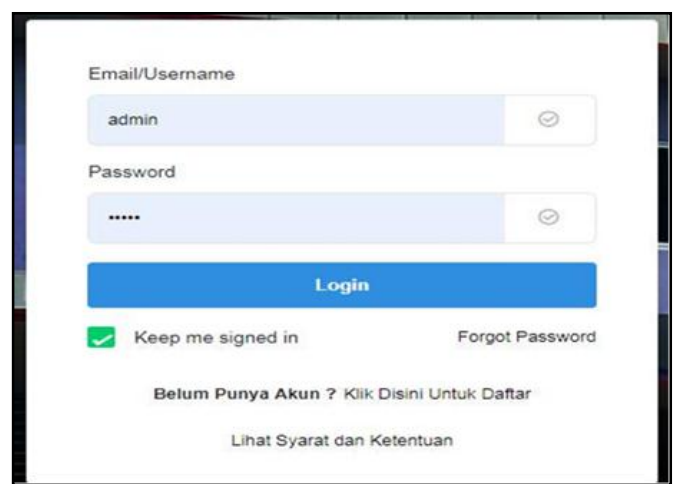

Fig. 2 Login page

Fig. 3 shows on Login page, students can see the terms and conditions following the PMDK Scholarship selection. This page shown in "Bahasa" Indonesian Language. 


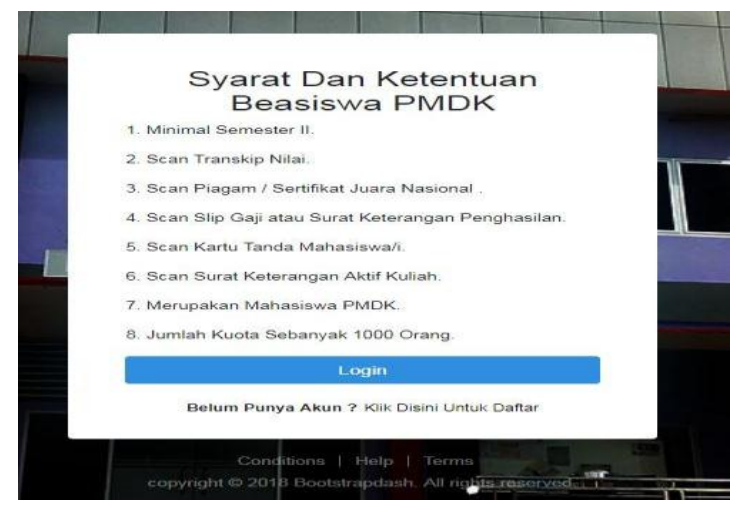

Fig. 3. Scholarship terms and conditions page

Fig. 4 is the main page, this main page consists of several menus in the system including dashboard page, student data page menu, criteria data page, sub criteria data page, Scholarship data page menu, scholarship submission data page menu, calculation page menu, report page, change password page, and logout menu.

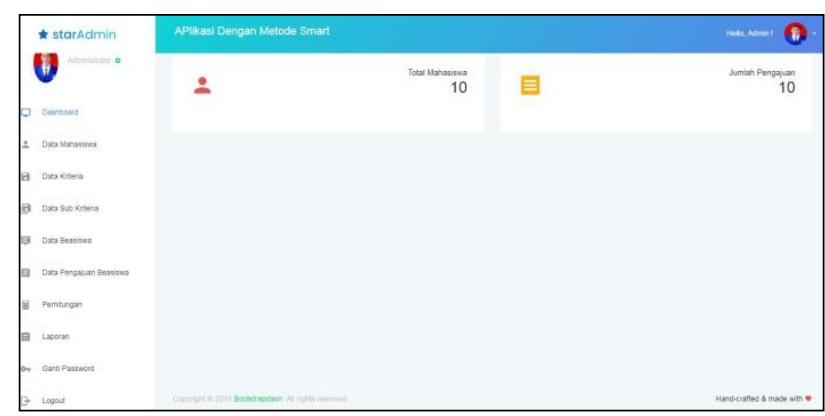

Fig. 4. Main page

Fig. 5 is the student data page. This student data page consists of number, name, name, photo, email, place of birth, address, department, semester, GPA, occupation, father's name, mother's name, father's address, mother's address, father's occupation, mother's occupation, mobile phone number, organizational position, non-academic achievement. Add data to add student data, action edit button to edit student data, delete button to delete student data, reset button to change student password.

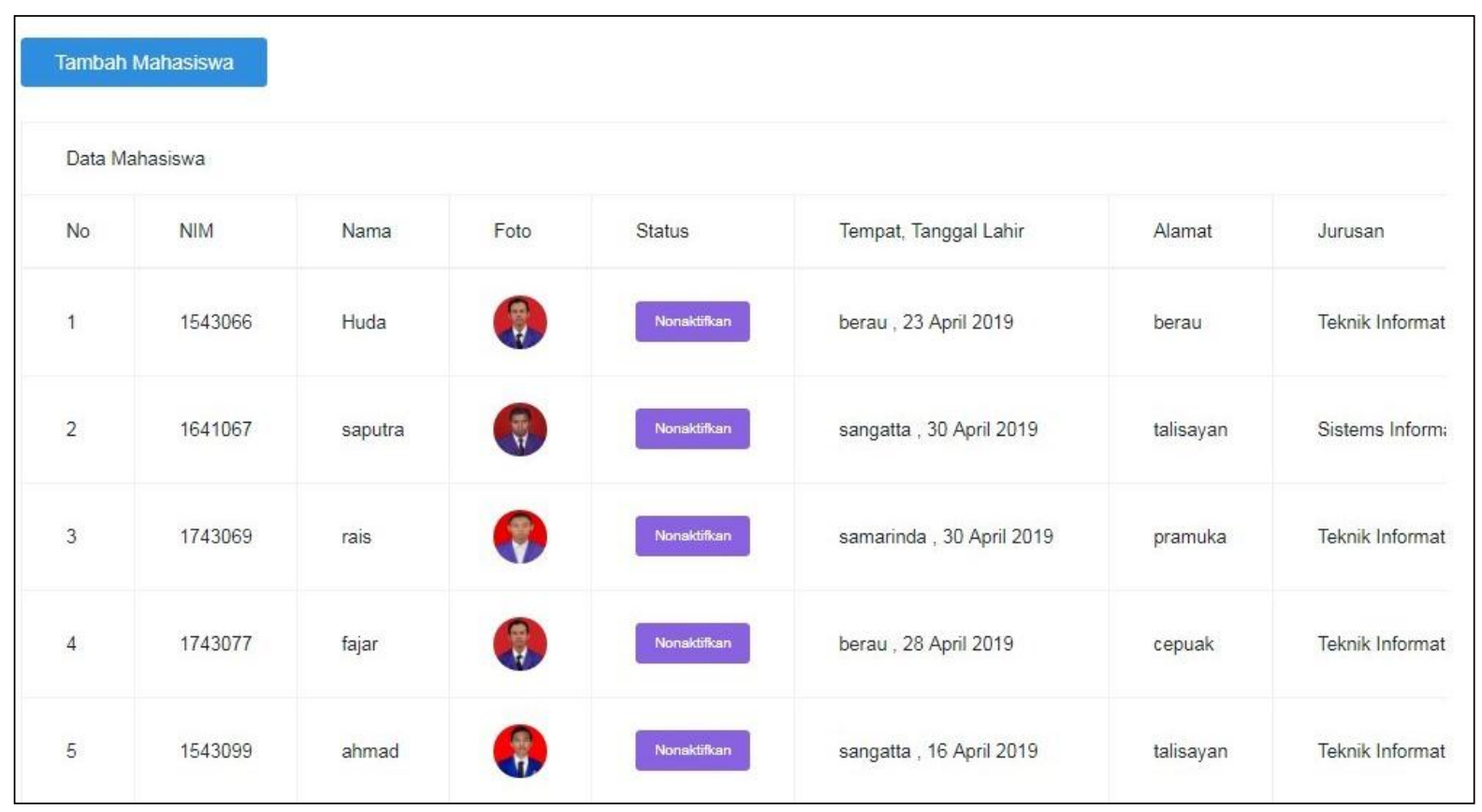

Fig. 5. Student data pages 
Fig. 6 is the criteria page, this criteria page consists of no, criteria name, weight, normalization, action button edit button to edit criteria, action button deletes to delete student data, and add criteria to add criteria.

\begin{tabular}{|c|c|c|c|c|c|}
\hline \multicolumn{6}{|c|}{ Tambah Kriteria } \\
\hline \multicolumn{6}{|c|}{ Data Kriteria } \\
\hline No & Nama & Bobot & Normalisasi & Aksi & \\
\hline 1 & Penghasilan Orang Tua & 30 & 0.3 & Edit & Hapus \\
\hline 2 & Juara prestasi non akademik & 20 & 0.2 & Edit & Hapus \\
\hline 3 & Aktif Organisasi & 10 & 0.1 & Edit & Hapus \\
\hline 4 & IP Semester/ IPK & 40 & 0.4 & Edit & Hapus \\
\hline
\end{tabular}

Fig. 6. Page criteria

Fig. 7 is the sub criterion page. This sub-criterion page consists of no, criteria, value sub-criteria, action added subcriteria to add sub-criteria, edit button action to edit sub-criteria, delete button action to delete criteria. Sub-criteria data will be saved in the sub-criteria table.

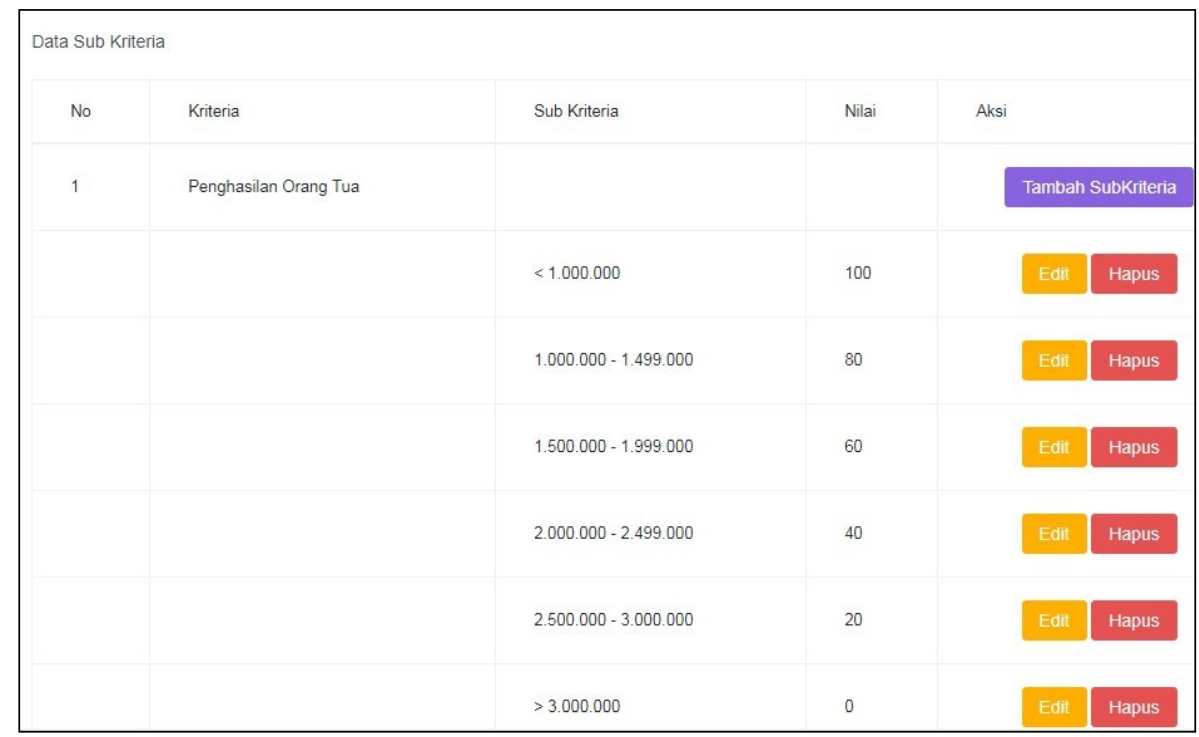

Fig. 7. Page sub criteria

Fig. 8 is the scholarship data page. The scholarship data page consists of number, scholarship name, registration date, closing date, open and closed status, and edit button action to edit scholarship opening and closing dates.

\begin{tabular}{|c|c|c|c|c|c|c|}
\hline No & Nama Beasiswa & Tanggal Pendaftaran & Tanggal Penutupan & Kuota & Status & Aksi \\
\hline 1 & Beasiswa PMDK & 19 Juli 2019 & 30 September 2019 & 1000 & DIBUKA & Edit \\
\hline
\end{tabular}

Fig. 8. Scholarship data page 
Fig. 9 is a scholarship submission page, this scholarship submission page consists of a number, number, name, photo, file, form action for printed forms, verification action for file verification, edit button action for editing scholarship submission.

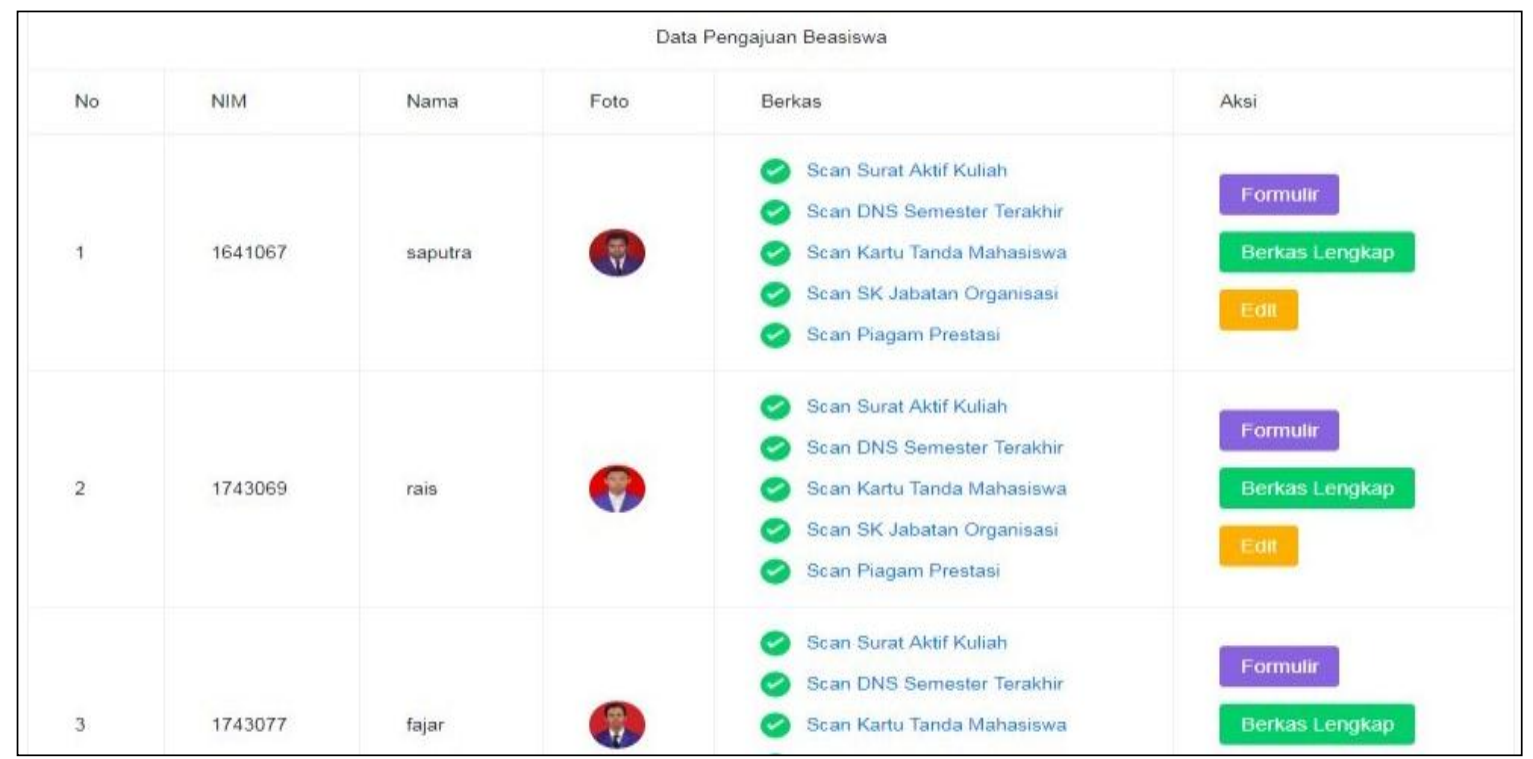

Fig. 9. Scholarship submission data page

Fig. 10 calculation pages, this calculation page consists of a number, name, utility value, results, recommendations, and edit action for editing student assessment.

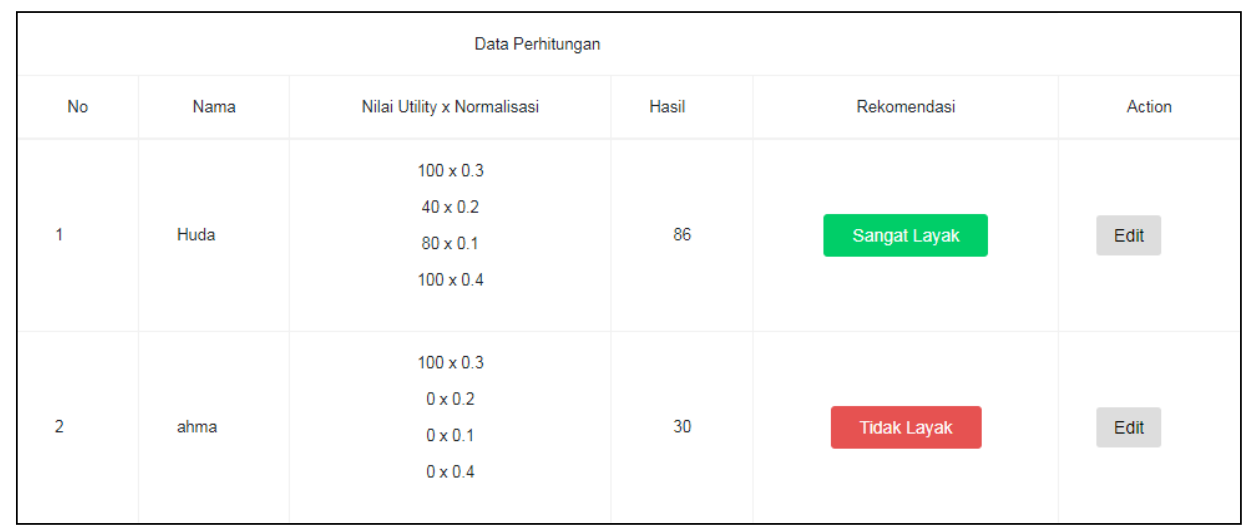

Fig. 10. Calculation page

Fig. 11 is the report page, this report page consists of number, name, name, place of birth date, grades, recommendations, print action for printing semesters, students, feasible and improper. 


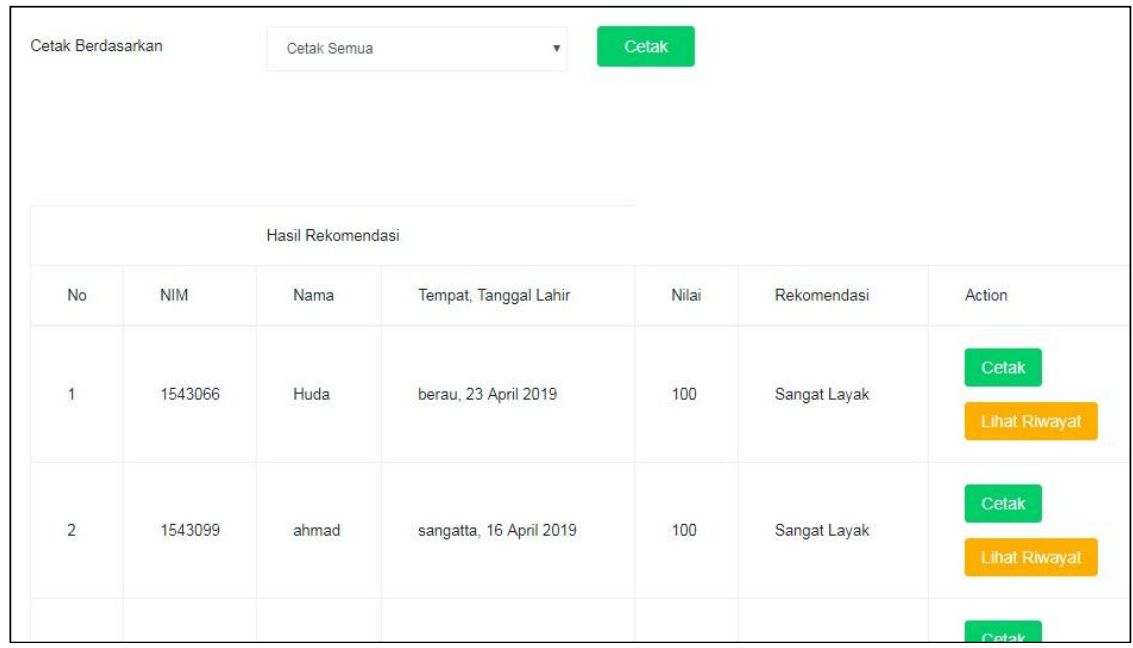

Fig. 11. Report page

Fig. 12 reports on the results of overall decisions, reports on the results of this decision are taken from the overall printout of students.

\begin{tabular}{|c|c|c|c|c|c|c|c|c|}
\hline & & & \multicolumn{6}{|c|}{$\begin{array}{l}\text { SEKOLAH TINGGI MANAJEMEN INFORMATIKA dan KOMPUTER } \\
\text { WIDYA CIPTA DHARMA } \\
\text { Status Terakreditasi Badan Akreditasi Nasional Perguruan Tinggi } \\
\text { Jl.M. Yamin No 25 Samarinda - Kalimantan Timur 75123 Telp. 0541 - 736071 Fax. 203492, } 734468 \\
\text { Email : wicida@wicida.ac.id }\end{array}$} \\
\hline \multicolumn{9}{|c|}{$\begin{array}{l}\text { HASIL PENGUMUMAN Beasiswa PMDK } \\
\text { TA. GASAL 2020/2021 }\end{array}$} \\
\hline No & NIM & Nama & Tempat, Tanggal Lahir & Jurusan & Semester & Nilai & Status & Riwayat \\
\hline 1 & 1543011 & yusuf & berau, 01 April 2019 & \begin{tabular}{|l|} 
Teknik Informatika \\
\end{tabular} & \begin{tabular}{|l|l}
8 & \\
\end{tabular} & 100 & Sangat Layak & 1. Beasiswa PMDK T.A. 2019/202 \\
\hline 2 & 1541077 & yusri & samarinda, 08 April 2019 & \begin{tabular}{|l|} 
Teknik Informatika \\
\end{tabular} & 8 & 100 & Sangat Layak & 1. Beasiswa PMDK T.A. 2019/2020 \\
\hline 3 & 1543066 & Huda & berau, 23 April 2019 & Teknik Informatika & 7 & 86 & Sangat Layak & \begin{tabular}{|l} 
1. Beasiswa PMDK T.A. $2019 / 2020$ \\
2. Beasiswa PMDK T.A. 2019/2020
\end{tabular} \\
\hline 4 & 1641067 & saputra & sangatta, 30 April 2019 & Sistems Informasi & 6 & 86 & Sangat Layak & 1. Beasiswa PMDK T.A. 2019/2020 \\
\hline & 1743069 & rais & samarinda, 30 April 2019 & Teknik Informatika & 4 & 74 & Layak & 1. Beasiswa PMDK T.A. 2019/2020 \\
\hline 6 & 1743077 & fajar & berau, 28 April 2019 & Teknik Informatika & 4 & 74 & Layak & 1. Beasiswa PMDK T.A. 2019/2020 \\
\hline 7 & 1543099 & ahmad & sangatta, 16 April 2019 & Teknik Informatika & 8 & 60 & Dipertimbangkan & 1. Beasiswa PMDK T.A. 2019/202 \\
\hline 8 & 1743065 & ibnu & 123456, 18 April 2019 & Teknik Informatika & 4 & 60 & Dipertimbangkan & 1. Beasiswa PMDK T.A. 2019/2020 \\
\hline & 1543088 & \begin{tabular}{|l|l} 
fathul \\
\end{tabular} & samarinda, 20 Maret 2001 & Teknik Informatika & 7 & 60 & Dipertimbangkan & 1. Beasiswa PMDK T.A. 2019/2020 \\
\hline & 1543211 & $\operatorname{amin}$ & berau, 10 April 2019 & \begin{tabular}{|l|} 
Teknik Informatika \\
\end{tabular} & 8 & 4 & Tidak Layak & 1. Beasiswa PMDK T.A. 2019/2020 \\
\hline \multicolumn{9}{|c|}{$\begin{array}{l}\text { Samarinda, } 23 \text { April } 2019 \\
\text { Ketua, STIMIK Widya Cipta Dharma }\end{array}$} \\
\hline
\end{tabular}

Fig. 12. Report on overall computer results

\section{Conclusion}

Based on the results of the implementation and testing of the Scholarship Selection Decision Support System for PMDK pathways at STMIK Widya Cipta Dharma Samarinda Using the SMART Method, it can be concluded that the PMDK Scholarship selection decision support system using the SMART method, the design, and construction of this website uses PHP programming topics and MySql as a database. Scholarship selection decision support system for PMDK path using the SMART method can help the STMIK Widya Cipta Dharma Samarinda in making the right decision in selecting students who pass the selection by the criteria, sub-criteria, and assessment of each criterion that has been determined by the collage. Scholarship selection decision support system for PMDK pathways at STMIK Widya Cipta Dharma, students register online, then submit a hard copy, after that admin verifies files, the admin can input student data, criterion data, sub-criterion data, and assessment processes, and can print reports.

The advice that can be given to developing this research is a decision support system for PMDK scholarship selection using the Web-based SMART method, so it is recommended that in the future this system be developed into a better mobile version, such as the Android platform. It is expected that the PMDK Scholarship selection decision support system can be considered for use on the STMIK Widya Cipta Dharma Samarinda. 


\section{Acknowledgment}

This research is funded by Directorate General of Strengthening for Research and Development and Ministry of Research, Technology and Higher Education of the Republic of Indonesia according the Research Contract in Fiscal Year of 2020

\section{References}

[1] Akyildiz, I. F., \& Kak, A. (2019). The Internet of Space Things/CubeSats: A ubiquitous cyber-physical system for the connected world. Computer Networks, 150, 134-149.

[2] Hyland, K. (2019). Second language writing. Cambridge university press.

[3] Kruglanski, A. W., Shah, J. Y., Fishbach, A., \& Friedman, R. (2018). A theory of goal systems. In The motivated mind (pp. 215-258). Routledge.

[4] Adair, J. (2019). Decision Making and Problem Solving: Break Through Barriers and Banish Uncertainty at Work. Kogan Page Publishers.

[5] Vohs, K. D., Baumeister, R. F., Schmeichel, B. J., Twenge, J. M., Nelson, N. M., \& Tice, D. M. (2018). Making choices impairs subsequent self-control: A limited-resource account of decision making, self-regulation, and active initiative. In Self-regulation and self-control (pp. 45-77). Routledge.

[6] Greco, S., Figueira, J., \& Ehrgott, M. (2016). Multiple criteria decision analysis. New York: Springer.

[7] Hernández-Julio, Y. F., Prieto-Guevara, M. J., Nieto-Bernal, W., Meriño-Fuentes, I., \& Guerrero-Avendaño, A. (2019). Framework for the development of data-driven Mamdani-type fuzzy clinical decision support systems. Diagnostics, $9(2), 52$.

[8] Davis, W. S., \& Yen, D. C. (Eds.). (2019). The information system consultant's handbook: Systems analysis and design. CRC press.

[9] Seabridge, A., \& Moir, I. (2020). Design and development of aircraft systems. John Wiley \& Sons.

[10] de Vries, L., \& Bligård, L. O. (2019). Visualising safety: The potential for using sociotechnical systems models in prospective safety assessment and design. Safety science, 111, 80-93.

[11] Hocken, R. J., \& Pereira, P. H. (Eds.). (2016). Coordinate measuring machines and systems. CRC press.

[12] Prasad, R., \& Rohokale, V. (2020). Internet of Things (IoT) and Machine to Machine (M2M) Communication. In Cyber Security: The Lifeline of Information and Communication Technology (pp. 125-141). Springer, Cham.

[13] Birkland, T. A. (2019). An introduction to the policy process: Theories, concepts, and models of public policy making. Routledge.

[14] Bell, C. (2019). Installing the MySQL Shell. In Introducing MySQL Shell (pp. 29-73). Apress, Berkeley, CA.

[15] Siahaan, V., \& Sianipar, R. H. (2020). The Best Tutorial to Learn Database Programming with Java GUI, MariaDB, and SQL Server. SPARTA PUBLISHING.

[16] Tate, M. A. (2018). Web wisdom: How to evaluate and create information quality on the Web. CRC Press.

[17] Johnson, P. (2018). Fundamentals of collection development and management. American Library Association.

[18] Siregar, D., Arisandi, D., Usman, A., Irwan, D., \& Rahim, R. (2017, December). Research of simple multi-attribute rating technique for decision support. In Journal of Physics: Conference Series (Vol. 930, No. 1, p. 012015). IOP Publishing.

\section{Authors' Profiles}

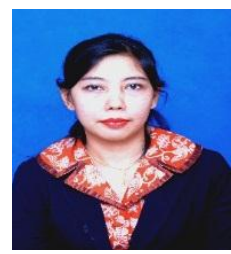

Vilianty Rafida is a lecturer of Informatics Engineering in STMIK Widya Cipta Dharma Samarinda. She obtained her bachelor degree from Informatics Engineering in Sekolah Tinggi Sains dan Teknologi Indonesia Bandung (1996). She also obtained Master Degree from Software Engineering in STMIK Eresha Jakarta (2011). Her research interests included Simulation and Modelling System, Distributed Data Processing, Operational Research Techniques, Compilation of Techniques. Computer Graphics.

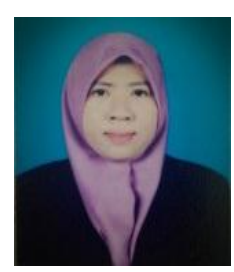

Wiwik Widiyatni, is a lecture of Informatics management in STMIK widya cipta Dharma Samarinda. She is obtained her bachelor degree from forestry management in 17 Agustus 1945 University Samarinda (2001). She also obtained Master Degree from Magister Management Agribisnis in Gadjah Mada University Yogyakarta (2003). Her research interests include Motivation and Commitment of PT. Segera Timber Co.Ltd 


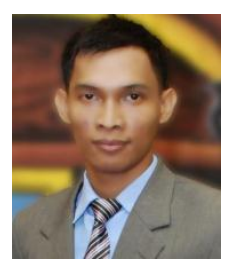

Bartolomius Harpad is head of Computer Laboratory in STMIK Widya Cipta Dharma. He is a lecture of Information System Department in STMIK widya cipta Dharma Samarinda since 2012. He is also an alumnus of this collage. He obtained Master Degree from Business Engineering in STMIK Eresha Jakarta (2014).

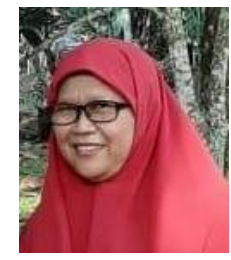

Hj. Ekawati Yulsilviana is head of Quality Assurance Department in STMIK Widya Cipta Dharma (2019). Previously, she is head of Administration Academic since 2004. She is a senior lecture and she has worked at STMIK Widya Cipta Dharma for 19 years. Now she is a PhD candidate of economic doctoral program in Mulawarman University.

How to cite this paper: Vilianty Rafida, Wiwik Widiyatni, Bartolomius Harpad, Ekawati Yulsilviana, " Implementation of Multiattribute Rating Technique Simple in Selection of Acceptance Scholarship of PMDK (Case Study: STMIK Widya Cipta Dharma)", International Journal of Modern Education and Computer Science(IJMECS), Vol.13, No.1, pp. 22-33, 2021.DOI: 10.5815/ijmecs.2021.01.02 